Research, Society and Development, v. 9, n.10, e8959109458, 2020

(CC BY 4.0) | ISSN 2525-3409 | DOI: http://dx.doi.org/10.33448/rsd-v9i10.9458

\title{
Requirements for Death in Dismissal of Constitutional Justices
}

Requisitos para morte em destituição de juízes constitucionais

Requisitos de muerte en destitución de jueces constitucionales

Received: 10/20/2020 | Reviewed: 10/20/2020 | Accept: 10/23/2020 | Published: 10/24/2020

Tomy Michael

ORCID: https://orcid.org/0000-0003-1707-6119

Faculty of Law, Universitas 17 Agustus 1945 Surabaya, Indonesia

E-mail: tomy@untag-sby.ac.id

\begin{abstract}
This study aims to find answers to the suitability of the conditions for death in the dismissal of constitutional judges. The inclusion of death requirements in Law no. 7-2020 violates the true essence of death. Passing away cannot be regulated and it is better if the sound of the article is changed, which initially dismissed a constitutional judge with respect from becoming a constitutional judge to stop immediately if ....and death must be removed unless there is a better condition for this to happen.
\end{abstract}

Keywords: Constitutional; Dismissal; Judge death.

\section{Resumo}

Este estudo tem como objetivo buscar respostas sobre a adequação das condições de morte na destituição de juízes constitucionais. A inclusão dos requisitos de morte na Lei no. 7-2020 viola a verdadeira essência da morte. $\mathrm{O}$ falecimento não pode ser regulamentado e é melhor se o som do artigo for alterado, que inicialmente dispensou um juiz constitucional de se tornar um juiz constitucional para parar imediatamente se ... e a morte deve ser removida a menos que haja uma condição melhor para isso acontecer.

Palavras-chave: Constitucional; Demissão; Julgue a morte.

\section{Resumen}

Este estudio tiene como objetivo encontrar respuestas a la idoneidad de las condiciones de muerte en la destitución de jueces constitucionales. La inclusión de requisitos de muerte en la Ley núm. 7-2020 viola la verdadera esencia de la muerte. El fallecimiento no se puede regular y es mejor si se cambia el sonido del artículo, que inicialmente destituyó a un juez 
(CC BY 4.0) | ISSN 2525-3409 | DOI: http://dx.doi.org/10.33448/rsd-v9i10.9458

constitucional con respecto a convertirse en juez constitucional para detenerse inmediatamente si ... y la muerte debe ser removida a menos que exista una mejor condición para que esto suceda.

Palabras clave: Constitucional; Despido; Juzga la muerte.

\section{Introduction}

Referring to the function of law, it's known that integrating the interests of members of society is carried out by regulating, the law doesn't only pay attention to the relationship from the aspect of order, but also the law must be able to determine certain measurements or parameters which are often referred to in law as the value of justice, there are even people who think that law is inseparable and must be combined with justice so that the law truly has meaning as law.(Stern, 2017) From this perspective, not everything must be regulated in statutory regulations. The existence of differences in legal reasoning will also affect good and clear legal arguments. Legal arguments must understand the sources of formal law, namely laws, customs and traditions, treaties, treaties, permanent jurisprudence and doctrine.(Juanda, 2017)

In researching the statutory regulations using the Law of the Republic of Indonesia Number 7 of 2020 concerning the Third Amendment to Law Number 24 of 2003 concerning the Constitutional Court (Law No.7-2020) which is said to have died as a reason to dismiss constitutional judges. Questioning the conditions for death can be resolved legal interpretation based on the thinking of the character Lucius Annaeus Seneca. There is very little research on the interpretation of death in law, but in this study, it uses four originalities, namely using euthanasia as a way out of dealing with incurable diseases, while the patient is already dying and torturing. In such a situation, it's not uncommon for patients to ask to be freed from this suffering and don't want to have their life extended again or in other circumstances the patient who is already unconscious, the patient's family who cannot bear to see a patient who is full of suffering before his death asks the doctor or nurse not to continue. treatment or if necessary give drugs that hasten death. This is where the term euthanasia appears, which is letting go of one's life in order to be free from suffering or to die properly. Euthanasia is still an act that is prohibited in the criminal law system and health law in Indonesia, whatever and whatever the reasons used and whoever submits both individuals who want themselves and their families are still prohibited from committing lethal injection, even health workers are still it's prohibited to carry out lethal injection for any reason.(Pradjonggo, 2016) The 
difference with this research isn't that the cause of death is an honor in completing a task. Javanese society views death not as a transfer of new status for the dead. All status that was carried during life was stripped naked, replaced by the image of a noble life. In this case the meaning of death for the Javanese refers to the meaning of returning to the origin of existence (sangkan paraning dumadi). Death in Javanese culture is always performed by the deceased by a ritual. After a person dies, it is usually accompanied by a prayer ceremony, offerings, salvation, distribution of inheritance, debt settlement and so on. In the Islamic perspective, Allah SWT is actually the one who created humans who gave life by being born into the world, then picked them up with death to face Him and would return to Him. That is the line determined by Allah to His creatures, no one is born into this world and then lives forever. The wheel of this world keeps turning and alternating life and death on this earth, this law applies to anyone regardless of the sex of male or female, old or young, poor or rich, the people or officials. In short, all kinds of differences in caste and social status must all comply with the natural laws that have been determined by Allah SWT (sunnatullah).(Karim, 2015) Passing away is associated with the perspective of ethnicity and settlement in Islam, emphasizing more on the process towards the end result. The next research is that there is a verdict in the case of Lanjar Sriyanto for negligence in driving which resulted in his wife's death and his son being injured, in his legal considerations he has used progressive thinking, namely even though Lanjar Sriyanto in fact and the evidence presented has fulfilled the elements of the article formulation that the accused is accused of but the judge judging by using the human basis and the condition of Lanjar Sriyanto, there is no reproachable character for Lanjar Sriyanto and excuses so that the judge decided that Lanjar Sriyanto did not need to serve a criminal sentence. Judges at the High Court and Supreme Court levels have changed the decision of the District Court Judge so that he stated that Sriyanto has fulfilled the formulation of offenses and deserves to be convicted. So because judges at the High Court and Supreme Court levels only look at the application of the law instead of seeing directly the condition of Lanjar Sriyanto, it's felt that justice hasn't been presented as mandated by social justice in Pancasila, the judge's code of ethics, the judicial power law. Judges not only decide based on the formulation of the articles being accused, but judges are obliged to apply the values contained in Pancasila, the Judge's Code of Ethics, the Judicial Power Act Judges upholding the law must also uphold the values that live in society including the value of social justice.(Haryadi, 2017) This research has a different concept with the meaning of death as the main cause in the process of dismissing constitutional judges. 
Based on this, this research focuses on the search for the meaning of death, is it appropriate as a condition in dismissing constitutional judges?

\section{Methodology}

This research uses normative legal research and normative legal research methods with a statutory approach and historical interpretation.(Michael, 2017) This research aims to find answers to the suitability of the requirements for death in dismissing constitutional judges.

\section{Results and Discussion}

\section{Legal Justice in Legal Norms}

The form of legal justice in a legal norm isn't always the same because legal norms have different ends. Legal justice is stated as a concrete problem so that the perspective of juridical positivism is in an absolute sense. Legal positivism is often seen as a legal school that separates law from morals and religion, between das solen and das sein. Positivism states that natural science is the only true source of knowledge and rejects activities related to metaphysics.(Dewi, 2019) Does a death that isn't known for its certainty tend to be considered a good thing? Terms of Law No. 7-2020 in full, especially in Article 23 that constitutional judges are dismissed with respect on the grounds of passing away, resigning those submitted to the constitution, being 70 (seventy) years old, physically or mentally ill for 3 (three) months so that they cannot carry out their duties as proven by a doctor's certificate. The existence of various conditions regarding the terms of dismissal will lead to different interpretations. Legal justice in this perspective is an idea.

Watch for death in Batak customs. The symbolic meaning of Tor-tor Sombah in the traditional vegetable matua (sayur matua) death ceremony, how is the relationship between Tor-tor Sombah Sombah and the traditional vegetable matua(sayur matua) death ceremony in the Simalungun Batak tribe, and the form of Tor-tor Sombah Sombah's performance in the traditional vegetable matua(sayur matua) death ceremony. Tor-tor Sombah Tor-tor Sombah in the traditional ceremony of death of sayur matua for the Batak Simalungun people is carried out as a conveyance of respect for children to parents who have died. Tor-tor Sombah in the life of the Batak Simalungun tribe is interrelated and is part of the tradition which is 
moved symbolically in traditional ceremonies. Tor-tor Sombah has meaning and symbols in the elements of the dishes that are displayed, namely: in hand gestures, musical accompaniment, clothing, make-up, properties, and umpala. The movements of the hands found in the Sombah Tor-tor have three forms, namely: arrogant, mangalo-alo, mamasumasu. Apart from showing that the Tor-tor Sombah has symbolic meaning, it is also related as a communication medium, and through the movements presented there is interaction between ceremony participants. Tor-tor Sombah is part of the culture that functions to maintain and maintain the continuity of the social system in the Simalungun Batak tribe. (Purba \& Slamet, 2019)

Referring to legal and social views, justice is a multidisciplinary part and results in legal justice being difficult to understand in the context of a thought.(Levett \& Thompson, 2015) In addition, it has the orientation of justice belonging to John Rawls that (Dionigi \& Kleidosty, 2017) Referring to the article above that legal justice is only for those who die because the definition of death is considered a good thing regardless of why he died. For example, did a constitutional judge die due to consuming narcotics while in a bar and died? Of course, such an assumption for a person's death isn't a justice that is accepted by a constitutional judge. (Ward \& Beech, 2015).

\section{Died Seneca Perspective}

In one text in the book "A Classic Guide to Dying" it is known that humans are more concerned with life than death. It is said that the seekers made up all of this for the sake of imagination, and disturbed our minds with terror. Death will cancel all sorrow, an end that cannot be passed by disease, returning us to the peace that shaded us before birth. Whoever pity the dead, let him also pity those who have not been born. The saying that he died too soon, was still young was honestly the definition of fear of death. In a legal perspective, the fear of death cannot be measured but how to prevent it from arising. There are several laws and regulations related to preventing death, namely:

1. Elucidation of Article 206 letter b of Law of the Republic of Indonesia Number 1 of 2009 concerning Aviation that what is meant by "area of possible accident hazard" is a part of the approach area which is directly adjacent to the ends of the runway and has a certain size, which can cause an accident hazard. 
2. Article 3 of the Law of the Republic of Indonesia Number 22 of 2002 concerning Clemency, states that the application for clemency does not delay the implementation of a verdict for the convict, except in the case of a death penalty decision.

In this perspective, death is often a cause for concern and there is no protection for the community.(Staley, 2010) A philosophy that saw self-possession as the key to an existence lived 'in accordance with nature', Stoicism called for the restraint of animal instincts and the severing of emotional ties.(Seneca] \& Seneca], 2016) Of course, the condition to die must be understood as part of from life and need not be used as the determination of a constitutional judge to act.

Noting Leahy considers the importance of the discussion of humans through a systematic philosophical perspective in a human philosophical thought for several reasons, as follows.

1. Humans are creatures that have special abilities and privileges to a certain extent.

2. Humans have a duty to investigate things deeply.

3. Humans have the awareness that humans are different from other creatures. One of the differences is that humans are equipped with responsibilities (Agastya, 2020)

Human rights are basic rights or citizenship that are inherent in an individual since he was born by nature which is given directly by God Almighty which cannot be deprived and deprived of it's existence and must be respected, upheld and protected by the state, law, government and everyone for the sake of honor and protection of human dignity. Indonesia is a country based on law. So that the State of Indonesia is obliged to provide human rights protection to every community. Meanwhile, a rule of law is a country based on the rule of law. Law is sovereign. The state is a legal subject, in the sense of rechtstaat. Because the state is seen as a legal subject, then if he is guilty, he can be prosecuted in front of a court for violating the law. (Hidayat, 2016)

\section{Conclusions}

The inclusion of death requirements in Law No. 7-2020 violates the true essence of death. Passing away cannot be regulated and it is better if the sound of the article is changed, which initially dismissed a constitutional judge with respect from becoming a constitutional judge to stop immediately if... and death must be removed unless there is a better condition 
for this to happen. For example, if you die because of a complication, then that too is the approval of the doctor and of course the causes of death are very many. Limitation on the definition of death also creates confusion. The cause of death was due to his belief in the meaning of death. In the end, the article sound focused more on the death of the conviction of the constitutional judge.

The suggestion that was conveyed was that there was a discussion of the draft law which actually used pure philosophy as its drafting. At times in the drafting of the bill, the definition of religion or belief is still mostly used. Such understanding actually creates injustice in realizing statutory regulations. It's better if in drafting a bill it also uses Seneca's thoughts in order to create a wise understanding in producing a legal norm.

\section{References}

Agastya, W. (2020). Kematian Menurut Louis Leahy. KENOSIS: Jurnal Kajian Teologi. https://doi.org/10.37196/kenosis.v5i2.78

Dewi, A. (2019). Injustice Positivisme Perspektif Moral Dan Etika Dalam Sistem Penegakan Hukum Pidana Di Indonesia. Legal Standing: Jurnal Ilmu Hukum. https://doi.org/10.24269/ls.v3i1.1664

Dionigi, F., \& Kleidosty, J. (2017). Theory of justice. In Theory of Justice. https://doi.org/10.4324/9781912303441

Haryadi, P. (2017). Pengembangan Hukum Lingkungan Hidup Melalui Penegakan Hukum Perdata Di Indonesia. Jurnal Konstitusi. https://doi.org/10.31078/jk1416

Hidayat, E. (2016). Perlindungan Hak Asasi Manusia Dalam Negara Hukum Indonesia. Asas: Jurnal Hukum Dan Ekonomi Islam.

Juanda, E. (2017). Hukum Dan Kekuasaan. Jurnal Ilmiah Galuh Justisi, 5(2), 177. https://doi.org/10.25157/jigj.v5i2.796

Karim, A. (2015). Makna Kematian Dalam Perspektif Tasawuf. Abdul Karim ESOTERIK JOURNAL p-ISSN: 2460-7576. 1(1). 2015 
Levett, L. M., \& Thompson, A. M. (2015). Law and Society. In International Encyclopedia of the Social \& Behavioral Sciences: Second Edition. https://doi.org/10.1016/B978-0-08097086-8.45065-8

Michael, T. (2017). Right To Have Rights. Mimbar Keadilan, 106. https://doi.org/10.30996/mk.v0i0.2203

Pradjonggo, T. S. (2016). Suntik Mati (Euthanasia) Ditinjau Dari Aspek Hukum Pidana Dan Hak Asasi Manusia Di Indonesia. Jurnal Ilmiah Pendidikan Pancasila Dan Kewarganegaraan. https://doi.org/10.17977/um019v1i12016p056

Purba, F. A., \& Slamet, S. (2019). Makna Simbolik Tor-To Rsombah Dalam Upacara Adat Kematian Sayur Matua Pada Masyarakat Suku Batak Simalungun. Gelar: Jurnal Seni Budaya. https://doi.org/10.33153/glr.v16i2.2490

Seneca], S. [Lucius A., \& Seneca], S. [Lucius A. (2016). On the Shortness of Life. In Oxford World's Classics: Seneca: Dialogues and Essays Book. https://doi.org/10.1093/oseo/instance.00136791

Staley, G. A. (2010). Seneca and the Idea of Tragedy. In Seneca and the Idea of Tragedy. https://doi.org/10.1093/acprof:oso/9780195387438.001.0001

Stern, S. (2017). The law. In Samuel Richardson in Context. https://doi.org/10.1017/9781316576755.028

Ward, T., \& Beech, A. R. (2015). Dynamic risk factors: a theoretical dead-end? Psychology, Crime and Law. https://doi.org/10.1080/1068316X.2014.917854

\section{Percentage contribution of each author in the manuscript}

$$
\text { Tomy Michael - 100\% }
$$

